\title{
Confirmation of sexual dimorphism in Hoplias aimara (Valenciennes, 1847) (Erythrinidae: Characiformes) proposed by local expertise in Amapá, Brazil
}

\author{
Gama, CS. ${ }^{a *}$ \\ aLaboratório de Ictiologia, Divisão de Zoologia, Instituto de Pesquisas Científicas e Tecnológicas do \\ Estado do Amapá - IEPA, Rodovia JK, Km 10 s/n, Fazendinha, CEP 68900-005, Macapá, AP, Brazil \\ *e-mail: cecilegama@hotmail.com
}

Received: June 19, 2012 - Accepted: April 11, 2013 - Distributed: August 31, 2014

(With 1 figure)

\begin{abstract}
Fishes may show sexual dimorphism according to their reproductive strategies. In some species, this differentiation is already well known. However, with the findings obtained from recent studies, the number of species for which sex can be determined without dissection has increased. Thus far, the presence of external secondary sexual characteristics in Hoplias aimara, a very well-studied species, has not been reported. Traditional knowledge evidenced through riparian people observations indicated the possibility of sexual dimorphism in this species, which was studied in 2 conservation units, Sustainable Development Reserve of Iratapuru River and Tumucumaque Mountains National Park, in the state of Amapá, Brazil. Fishes were captured, and their anal fins were examined when they were still fresh; the sex of the fishes was confirmed by dissection. The same procedure was used for formalin-fixed fishes. By assessing the shape of the anal fin in fresh or fixed fishes, it was possible to determine the sex of the fish, which was then confirmed by dissection. H. aimara shows sexual dimorphism expressed in the morphology of their anal fin. Thus, the sex of fishes deposited in collections can be identified without any dissection, thereby providing important biological information about the specimens.
\end{abstract}

Keywords: local knowledge, ethnoichthyology, Tumucumaque, Iratapuru.

\section{Confirmação do dimorfismo sexual em Hoplias aimara (Valenciennes, 1847) (Erythrinidae: Characiformes) proposto por ribeirinhos no Amapá, Brasil}

\section{Resumo}

Os peixes podem exibir dimorfismo sexual conforme suas estratégias reprodutivas. Em algumas espécies essa diferenciação já é bem conhecida, no entanto, novos estudos têm aumentado o número de espécies que não precisam de dissecção dos indivíduos para o reconhecimento do seu sexo. A espécie Hoplias aimara, apesar de muito bem estudada ainda não apresentava registro da presença de caracteres sexuais secundários externos. O conhecimento tradicional de ribeirinhos indicou a possibilidade da existência de dimorfismo sexual para esta espécie que foi estudada em duas unidades de conservação no Estado do Amapá, a Reserva de Desenvolvimento Sustentável do rio Iratapuru e o Parque Nacional Montanhas do Tumucumaque. Os indivíduos capturados, ainda frescos, tiveram sua nadadeira anal examinada e seu sexo confirmado através de sua dissecção. Indivíduos fixados também passaram pelo mesmo procedimento. Através do formato da nadadeira anal, seja em indivíduos frescos ou fixados, foi possível inferir o sexo de cada indivíduo, que foi confirmado através de sua dissecção. A espécie Hoplias aimara apresenta dimorfismo sexual manifestado na morfologia de sua nadadeira anal. Indivíduos depositados em coleções podem ter seu sexo observado sem sua dissecção, acrescentado informações importantes à biologia dos espécimes.

Palavras-chave: conhecimento local, etnoictiologia, Tumucumaque, Iratapuru.

\section{Introduction}

The evolution of secondary sexual characteristics is usually the result of a disparity in the parental investment of males and females (Trivers, 1972; Andersson, 1994). In some cases, this disparity can be exclusively attributed to size differences between males and females.
Many teleost fishes do not exhibit any sexual dimorphism, even during the spawning season, and do not show sexual characteristics or permanent ornaments. On the other hand, some fishes show permanently dimorphic traits that are not necessarily associated with internal fertilization (Rapp 
PY-Daniel and Fernandes, 2005). When present, sexual characteristics can be easily recognized in some species whereas, in others, a detailed examination is required for identification of these characteristics (Godinho, 2007). Typically, in any fish, sex can be determined by visual inspection of the gonads (primary sexual characteristics), which normally requires dissection; however, in mature fishes, these characteristics are quite evident.

Hoplias aimara (Valenciennes, 1847) is widely distributed, from Central America to Argentina. It is found in the tributaries in the middle and lower Amazon basin, including the Trombetas, Jari, Xingu, Tapajós, Araguari, and Tocantins rivers as well as the coastal rivers of Guyana, Suriname, and French Guiana (Planquette et al., 1996), where the fish is popularly known as trahiras or big trahiras. They live in a great number of habitats, varying from lotic environments such as large rivers and waterfalls to strictly lentic environments such as lakes and reservoirs (Oyakawa and Mattox, 2009). Despite being a very well-known and studied species, thus far, there have been no reports of sexual dimorphism in this genus.

The objective of this study was to prove the existence of sexual dimorphism in the species Hopliasaimara after riverine people indication that recognized accurately the sex of the individuals without the dissection of them.

\section{Methods}

In an expedition to the Jari River to inventory fish as a part of the Biodiversity Corridor project of Amapá (CI-Brasil/IEPA/IBAMA/GEA-Amapá), locally hired assistants confirmed the sex of captured big trahiras (H. aimara) without examining the gonads. About 3 of 6 boatmen hired stated that the sex of the fishes could be easily determined by simply analysing the shape of the anal fins. Since no related data for this species were available in the literature, it was necessary to confirm this characteristic by dissecting the gonads, which was performed for analysing and verifying the sex of the collected fishes.

Hoplias aimara is a species of large size and low population density, characteristics that difficult their collection, transportation and storage of specimens in collections.

Consequently, on capture of the fishes during subsequent expeditions in the context of the same mission, a process was initiated to confirm the information provided by the assistants, intensifying the fishery of this species. The fishes analysed were collected during expeditions to Sustainable Development Reserve of Iratapuru River and Montanhas do Tumucumaque National Park, which were state and federal conservation units, respectively. In Sustainable Development Reserve of Iratapuru River, specimens were captured between November 22 and 23, $2004\left(0^{\circ} 16^{\prime} 35^{\prime} \mathrm{N}\right.$, $\left.53^{\circ} 06^{\prime} 24^{\prime \prime} \mathrm{W}\right)$, from Jari River, municipality of Laranjal of Jari. In Montanhas do Tumucumaque National Park, specimens were captured between September 4 and 14, 2005 ( $3^{\circ} 29^{\prime} 51^{\prime \prime} \mathrm{N} ; 52^{\circ} 18^{\prime} 0$ '” W) from Anotai River, municipality of Oiapoque.
For fish collection, we used hooks stuck along the banks of local rivers in flat locations with little current. The anal fin of the collected specimens was observed and then dissected to confirm the sex. Considering the limited space available in the laboratory, which would have been insufficient for fixing and storing all specimens, photographic records of each specimen, including images of the gonads and the shape of the anal fin, were created.

Smaller specimens collected with gillnets in the same expedition in Montanhas do Tumucumaque National Park on November 03, 2005 (01²3'32’N; 51 '56'11’W), in Mutum River, municipality of Calçoene, were fixed with $10 \%$ formalin for laboratory examination. After 15 days, these fishes were washed and maintained in $70 \%$ alcohol solution. They were identified, after which their anal fins were observed, and the fishes were dissected for sex confirmation. Next, the specimens were deposited in the Scientific Collection Fauna of Amapá in the Institute of Scientific and Technological Research of Amapá (IEPA) under registration IEPA-2760.

\section{Results and Discussion}

A total of 6 specimens (4 males and 2 females) (Table 1) were captured from Jari River (Figure 1, specimens 01 to 05 ), while 5 specimens (4 females and 1 male) were obtained from Anotai River (Figure 1, specimens 06), total of 11 individuals collected. We observed the shape of the anal fins of all the captured fishes, which were dissected for sex confirmation. In $100 \%$ of the cases, the anal fin clearly indicated the sex of the fish, thus confirming the sexually dimorphic nature of this characteristic. The range of standard length of individuals analysed was 17.6 to $66 \mathrm{~cm}$.

In males, when the anal fin is projected forward of the fish body, its surface takes the form of a spoon or a shell (Figure 1.01) while in females, proceeding the same movement of the fin, this remains with the flat surface (Figure 1.06). This form of spoon may be more or less concave but in males, its surface never remains flat.

To verify whether this feature remained in fishes after fixation, the anal fins of 3 fixed fishes were observed, after which the specimens were dissected. The gonads of the fishes confirmed their sex, which was also indicated by the shape of the fins. These findings were obtained in 2 males with standard lengths of $20.0 \mathrm{~cm}$ and $19.1 \mathrm{~cm}$, and a female with a standard length of $17.6 \mathrm{~cm}$.

Secondary sexual characteristics do not develop when females and males equally invest in parental care.

Table 1. Total weight (Wt), standard length (Lp) and sex of the specimens of Hoplias aimara shown in Figure 1.

\begin{tabular}{crrc}
\hline Specimens & \multicolumn{1}{c}{ Wt } & Lp & sex \\
\hline 01 & $5 \mathrm{~kg}$ & $59 \mathrm{~cm}$ & male \\
02 & $4.5 \mathrm{~kg}$ & $56 \mathrm{~cm}$ & male \\
03 & $3.5 \mathrm{~kg}$ & $50.5 \mathrm{~cm}$ & female \\
04 & $3 \mathrm{~kg}$ & $50 \mathrm{~cm}$ & male \\
05 & $7.8 \mathrm{~kg}$ & $66 \mathrm{~cm}$ & male \\
06 & $1.5 \mathrm{~kg}$ & $26 \mathrm{~cm}$ & female \\
\hline
\end{tabular}




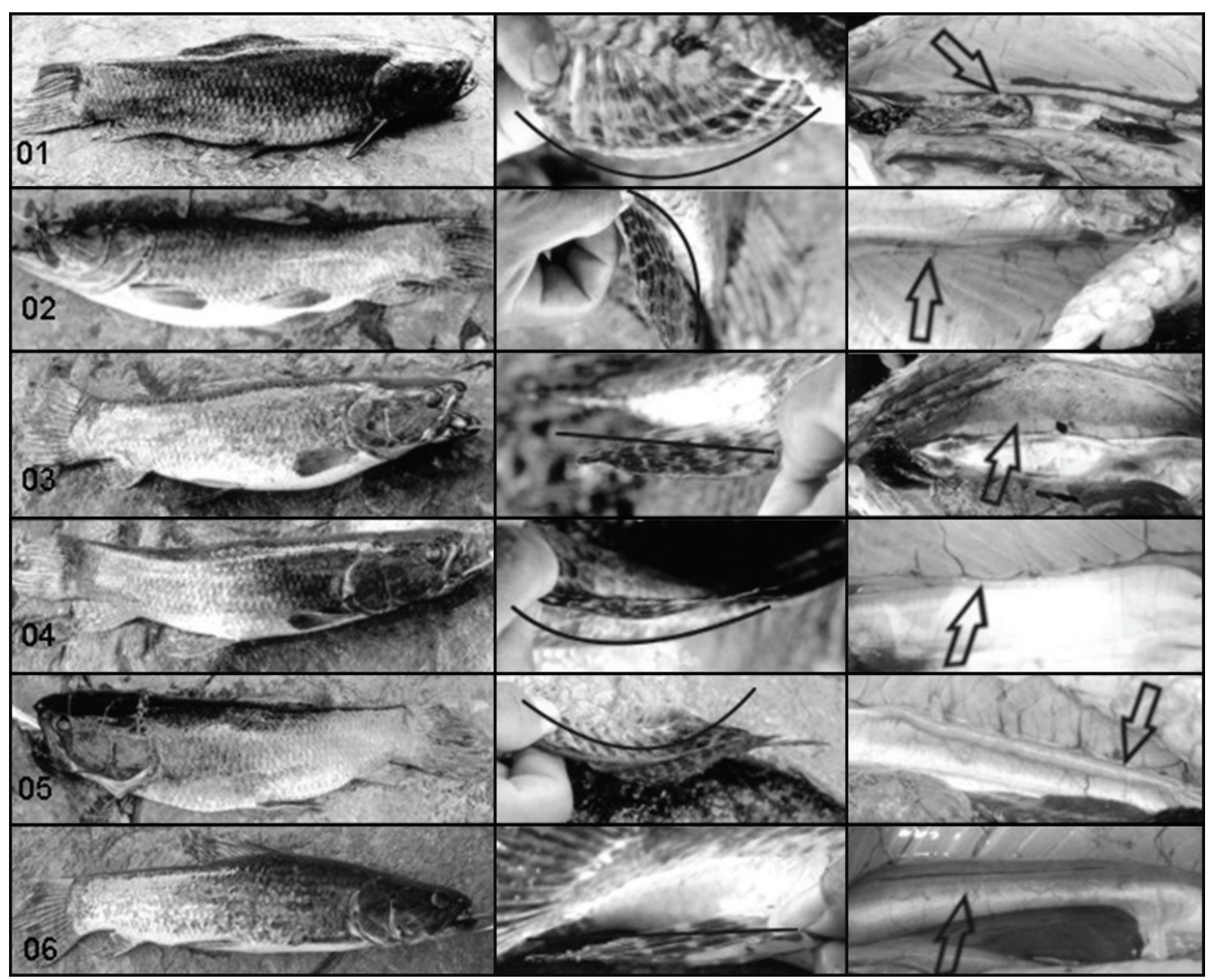

Figure 1. Specimens of Hoplias aimara examined fresh with their anal fins (lines indicating the format) and gonads (indicated by arrows).

However, when the investment in parental care is higher in males than in females, the females compete for males, and dimorphic traits such as ornaments and behavioral manifestation of these ornaments ("display") evolve among females. Finally, females that invest in parental care more than males represent the most common case: they compete among each other and evolve ornaments as well as behavioural manifestations of these ornaments (Power, 1980). Querol et al. (2003), Moreira (1921) and Azevedo and Gomes (1943) observed parental care in trahiras (Hoplias malabaricus), in which the male takes care of the nest and carefully responds to the presence of any predator. This form of parental care by the male fish has also been reported by Breder and Rosen (1966). These findings were observed in both induced and natural reproduction. In both cases, the male took care of the nest, and none of the authors mentioned above have found evidence of sexual dimorphism for this species. In keeping with this notion, it was expected that if there was sexual dimorphism in this species, it would have been expressed by females and not by males, unlike the findings described in this study.
However, it is important to emphasize that the causes, ecological or selective sexual, of sexual dimorphism do not need to be exclusive: sexual differences might evolve primarily due to sexual selection and subsequently be fixed by natural selection if the opposite sex shows differences in the use of ecological resources (Power, 1980).

Batista and Lima (2010) compared data generated by traditional knowledge about reproductive characteristics of Semaprochilodus spp and data generated by scientific experiments and found no significant differences between the two sources regarding several aspects. Comparison between local and scientific knowledge is a promising way to gather new ecological data, considering that these two sources of knowledge may complement each other and generate more reliable information.

Studies of Brazilian ethnoichthyologist pioneers have already shown that fishermen possess knowledge and carry out practices related to the structure and function of the ecosystems they inhabit.

The knowledge of the sex of individuals is important to conserve exploited fish species, as is the case of Hoplias aimara, once, knowing their reproductive period, females can be avoided by fishing for the maintenance of fish stocks. 


\section{Conclusion}

Hoplias aimara shows sexual dimorphism in the morphology of the anal fin in both fresh and fixed specimens. This information adds important data about this species, since this characteristic is visible even in fixed fishes and this process does not cause stiffening of the fins.

The sex of fishes deposited in collections can be observed without any dissection, thus providing important information about the biology of specimens.

In isolated areas with a history of few conducted studies, it is recommended to integrate popular knowledge into scientific research as a source of research themes to be verified.

\section{Acknowledgements}

Thanks to International Conservation (CI-Brasil), to Global Conservation Fund and to the Fundação Gordon and Betty Moore, together with Chico Mendes Institute of Biodiversity Conservation - (ICMBio - AP) and to Amapá State Government for the financial support for the implementation of the project.

Thanks to Dr. Osvaldo Oyakawa for help in identification of specimens and confirmation of dimorphic characters.

\section{References}

ANDERSSON, M., 1994. Sexual selection. Princeton: Princeton Univ. Press. 599 p.

AZEVEDO, P., GOMES, AL., 1943. Contribuição ao estudo da biologia da traíra Hoplias malabaricus (Bloch, 1974). Boletim da Indústria Animal, vol. 5, no. 4, p. 15-64.

BATISTA, VS. and LIMA, LG., 2010. In search of traditional bioecological knowledge useful for fisheries co-management: the case of jaraquis Semaprochilodus spp. (Characiformes, Prochilodontidae) in Central Amazon, Brazil. Journal of Ethnobiology and Ethnomedicine, vol. 6, no. 1, p. 15. http://dx.doi.org/10.1186/1746-4269-6-15. PMid:20525294

BREDER, CM. and ROSEN, DE., 1966. Models of reproduction in fishes. New York: American Museun of Natural History. 911 p.

GODINHO, HP., 2007. Estratégias reprodutivas de peixes aplicadas à aqüicultura: bases para o desenvolvimento de tecnologias de produção. Revista Brasileira de Reprodução Animal, vol. 31, p. 351-360.

MOREIRA, AC., 1921. A piscicultura no Brasil [peixe de água doce]. Rio de Janeiro. 13 p.

OYAKAWA, OT. and MATTOX, GMT., 2009. Revision of the Neotropical trahiras of the Hoplias lacerdae species-group (Ostariophysi: Characiformes: Erythrinidae) with descriptions of two new species. Neotropical Ichthyology, vol. 7, no. 2, p. 117-140. http://dx.doi.org/10.1590/S1679-62252009000200001.

PLANQUETTE, P., KEITH, P. and LE BAIL, P-Y., 1996. Atlas des poissons d'eau douce de Guyane: tome 1. Paris: Service du Patrimoine Naturel/Institut d'Écologie et de Gestion de la Biodiversité/Muséum National D'histoire Naturelle/Institut National de la Recherche Agronomique/Conseil Supérieur de la Pêche. Collection du Patrimoine Naturel, vol. 22.

POWER, HW., 1980. The foraging behavior of mountain bluebirds with special emphasis on sexual differences. Washington: The American Ornithological Union. p. 1-72. Ornithological Monographs, no. 28.

QUEROL, MVM., QUEROL, E., PESSANO, E., AZEVEDO, CLO., TOMASSONI, D., BRASIL, L. and LOPES, P., 2003. Reprodução natural e induzida de Hoplias malabaricus (Bloch, 1794), em tanques experimentais, na região de Uruguaiana, Pampa Brasileiro. Uruguaiana, PUCRS. Biodiversidade Pampeana, vol. 1, no. 1, p. 46-57.

RAPP PY-DANIEL, LH. and FERNANDES, CC., 2005. Dimorfismo sexual em Siluriformes e Gymnotiformes (Ostariophysi) da Amazônia. Acta Amazonica, vol. 35, no. 1, p. 97-110. http:// dx.doi.org/10.1590/S0044-59672005000100015.

TRIVERS, RL., 1972. Parental investment and sexual selection. In CAMPBELL, B. Sexual selection and the descent of man, 1871-1971. Los Angeles/Chicago: University of California/Aldine Publishing Company. p. 136-179 